\title{
Mutation spectrum in South American Lynch syndrome families
}

\author{
Mev Dominguez-Valentin ${ }^{1,2^{*}}$, Mef Nilbert ${ }^{1,2}$, Patrik Wernhoff ${ }^{3}$, Francisco López-Köstner ${ }^{4}$, Carlos Vaccaro ${ }^{5}$, \\ Carlos Sarroca ${ }^{6}$, Edenir Ines Palmero ${ }^{7}$, Alejandro Giraldo ${ }^{8}$, Patricia Ashton-Prolla ${ }^{9}$, Karin Alvarez ${ }^{4}$, Alejandra Ferro ${ }^{5}$, \\ Florencia Neffa ${ }^{6}$, Junea Caris ${ }^{7}$, Dirce M Carraro ${ }^{10}$ and Benedito M Rossi ${ }^{11}$
}

\begin{abstract}
Background: Genetic counselling and testing for Lynch syndrome have recently been introduced in several South American countries, though yet not available in the public health care system.

Methods: We compiled data from publications and hereditary cancer registries to characterize the Lynch syndrome mutation spectrum in South America. In total, data from 267 families that fulfilled the Amsterdam criteria and/or the Bethesda guidelines from Argentina, Brazil, Chile, Colombia and Uruguay were included.

Results: Disease-predisposing mutations were identified in 37\% of the families and affected $\mathrm{MLH1}$ in $60 \%$ and MSH2 in 40\%. Half of the mutations have not previously been reported and potential founder effects were identified in Brazil and in Colombia.
\end{abstract}

Conclusion: The South American Lynch syndrome mutation spectrum includes multiple new mutations, identifies potential founder effects and is useful for future development of genetic testing in this continent.

Keywords: Lynch syndrome, MLH1, MSH2, South America, Mutation

\section{Background}

Since the initial reports on disease-predisposing mutations in the mismatch-repair (MMR) genes MLH1 [MIM:120436], MSH2 [MIM:609309] and MSH6 [MIM:600678] in the early 1990 'ies, a large number of studies have contributed to the establishment of the molecular map of Lynch syndrome with over 3,072 unique genetic MMR gene variants identified. These data are predominantly based on studies from North America, Europe and Asia. The mutations affect MLH1 in $42 \%$, MSH2 in $33 \%$, MSH6 in $18 \%$ and PMS2 in $8 \%$ [1]. Nonsense mutations, frameshift mutations and missense mutations predominate, whereas large genomic rearrangements and splice-site variants constitute $<10 \%$ of the alterations [1].

The South American population is ethnically mixed from American Indian and European ancestors. In Uruguay and Argentina, European ancestry predominates. In Brazil, significant African and American Indians roots apply. In Chile, Colombia, Peru and Bolivia, Spanish colonist and American Indian ancestry influence the populations [2,3]. Mutation screening in South American families suspected of Lynch syndrome has identified disease-predisposing germline mutations in $M L H 1$ and $M S H 2$ in $16-45 \%$ of families that fulfill the Amsterdam criteria and/or the Bethesda guidelines [2-7]. Hereditary colorectal cancer registries have been established in Argentina, Brazil, Uruguay and Chile with the aim to collect and share data on the MMR gene mutation spectrum, identify potential founder mutations, interpret the role of unclassified genetic variants and to study cancer risks in the South American Lynch syndrome population. We used published data and unpublished register data to describe the mutation spectrum in South American Lynch syndrome families.

\section{Methods}

Ethics statement

All patients provided an informed consent for inclusion into the South American registers during genetic

\footnotetext{
${ }^{1}$ The Danish HNPCC Register, Clinical Research Centre, Hvidovre Hospital, Copenhagen University, Hvidovre, Denmark

2Department of Oncology, Institute of Clinical Sciences, Lund University, Lund, Sweden

Full list of author information is available at the end of the article
} 


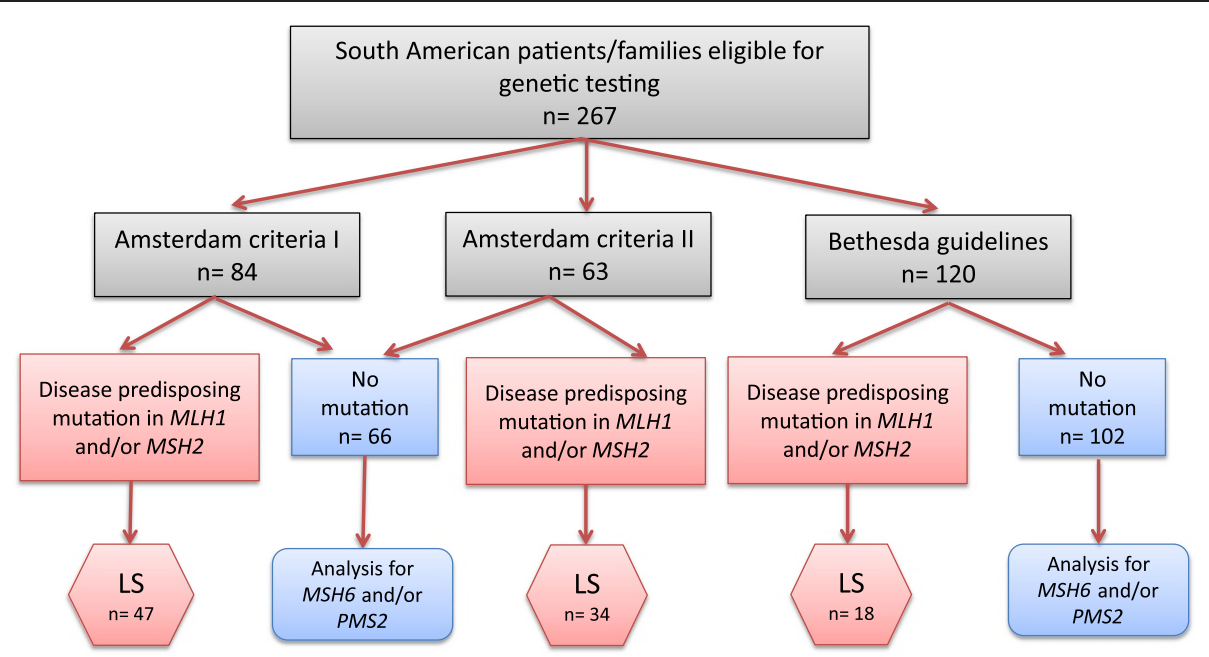

Figure 1 Flowchart of South American patients/families included in the study.

counseling sessions and is in compliance with the Helsinki Declaration.

\section{Patient selection}

Families that fulfilled the Amsterdam criteria [8,9] and/ or the Bethesda guidelines [10] were selected from the hereditary cancer registries at the Hospital Italiano (Buenos Aires, Argentina), the Hospital de las Fuerzas Armadas (Montevideo, Uruguay), the Clinica Los Condes (Santiago, Chile), the Barretos Cancer Hospital (Barretos, Brazil) and from two databases in Colombia and in Southeastern Brazil (Figure 1, Table 1) [2,3,5,11]. Patients were informed about their inclusion into the registries, which generally contained data on family history, age at onset and results of genetic testing.

\section{Disease-predisposing mutations}

Methods to assess MMR status, e.g. microsatellite instability analysis and MMR protein staining, varied between the countries and were excluded from the present study since these data were incomplete. Molecular diagnosis was generally based on direct sequencing of $M L H 1$ and $M S H 2$. Chilean and Brazilian families were also analyzed for large genomic rearrangements using the multiplex ligation-dependent probe amplification (MLPA) method (performed using the SALSA kit P003, MRC-Holland, Amsterdam, Netherlands).

\section{Mutation nomenclature}

Mutation nomenclature was in accordance with the Human Genome Variation Society (HGVS) guidelines [12]. Mutations in the $M L H 1$ or $M S H 2$ genes were considered deleterious if they: a) were classified as pathogenic in LOVD database; b) introduced a premature stop codon in the protein sequence (nonsense or frameshift mutation); c) occurred at donor or acceptor splice sites; or d) represented whole-exon deletions or duplications. All identified mutations were correlated to the MMR Gene Unclassified Variants Database (www.mmruv.info), the Mismatch Repair Genes Variant Database (http://www.med.mun.

Table 1 Summary of register data from MMR South American Lynch syndrome families

\begin{tabular}{|c|c|c|c|c|c|}
\hline South American Institutions & $\begin{array}{l}\text { Total number of } \\
\text { patients/families }\end{array}$ & $\begin{array}{l}\text { MMR mutation } \\
\text { carriers }\end{array}$ & $\begin{array}{c}\text { \% of MMR } \\
\text { mutation carriers }\end{array}$ & $\begin{array}{l}\text { Mean age at } \\
\text { CRC diagnosis }\end{array}$ & $\begin{array}{c}\text { Mean age at endometrial } \\
\text { cancer diagnosis }\end{array}$ \\
\hline Hospital Italiano (Buenos Aires, Argentina) & 28 & 14 & 50.0 & 44.3 (SD 6.2) & 46.3 (SD 5.5) \\
\hline $\begin{array}{l}\text { Hospital de las Fuerzas Armadas } \\
\text { (Montevideo, Uruguay) }\end{array}$ & 25 & 7 & 28.0 & $35.1(\mathrm{SD} 7.6)$ & $41.5(\mathrm{SD} 8.3)$ \\
\hline Clinica Las Condes ${ }^{a}$ (Santiago, Chile) & 50 & 20 & 40.0 & 35.7 (SD 10.7) & $41.1(\mathrm{SD} 8.8)$ \\
\hline Barretos Cancer Hospital ${ }^{a}$ (Barretos, Brazil) & 23 & 15 & 65.2 & 39.4 (SD 13.8) & 49.8 (SD 5.3) \\
\hline Colombia & 13 & 8 & 61.5 & NA & NA \\
\hline Southeastern Brazil & 128 & 35 & 27.3 & 42.3 (SD 11.4) & 48.8 (SD 2.4) \\
\hline Total & 267 & 99 & 37.1 & & \\
\hline
\end{tabular}

${ }^{a}$ MLPA analysis included, b Valentin et al. 2011 [3] and Rossi et al. 2002 [5], 'Giraldo et al. 2005 [2] and Alonso-Espinaco et al. 2011 [11], NA Information not available, MMR mismatch-repair genes, $S D$ standard deviation, $C R C$ colorectal cancer. 
Table 2 Spectrum of alterations in South American Lynch syndrome families

\begin{tabular}{|c|c|c|c|c|c|c|c|}
\hline Gene & Nucleotide & Consequence & Exon & Reported as & Country & $\begin{array}{l}\text { Number of } \\
\text { families }\end{array}$ & References \\
\hline \multirow[t]{40}{*}{$\overline{M L H 1}$} & c.1-?_116+?del & p.M1_C39> FfsX13 & 1 & Causal & Chile & 2 & InSIGHT \\
\hline & c.199G > A & p.G67R & 2 & Causal & Argentina & 1 & InSIGHT \\
\hline & $c .211 \mathrm{G}>\mathrm{T}$ & p.E71X & 3 & Causal & Brazil & 1 & InSIGHT \\
\hline & c. $289 \mathrm{~T}>\mathrm{G}$ & p.Y97D & 3 & VUS & Uruguay & 1 & InSIGHT \\
\hline & C. $336 \mathrm{~T}>\mathrm{A}$ & p.H112Q & 4 & VUS & Argentina & 1 & InSIGHT \\
\hline & c. $350 \mathrm{C}>\mathrm{T}$ & p.T117M & 4 & Causal & Uruguay & 2 & InSIGHT \\
\hline & $c .421 C>G$ & p.P141A & 5 & VUS & Colombia & 1 & Giraldo et al. 2005 [2] \\
\hline & c.503dupA & p.N168KfsX4 & 6 & Causal & Chile & 1 & InSIGHT \\
\hline & c.503delA ${ }^{a}$ & p.N168lfsX34 & 6 & Causal & Brazil & 1 & $\begin{array}{l}\text { Not previously } \\
\text { described }\end{array}$ \\
\hline & c. $545+3 A>G$ & & 6 & Causal & Brazil & 2 & InSIGHT \\
\hline & $c .588+2 \mathrm{~T}>\mathrm{A}^{\mathrm{a}}$ & & 7 & Causal & Brazil & 1 & $\begin{array}{l}\text { Valentin et al. } \\
2011[3]\end{array}$ \\
\hline & $c .588+5 G>C$ & & 7 & Causal & Brazil & 1 & InSIGHT \\
\hline & c.665delA & p.N222MfsX7 & 8 & Causal & Uruguay & 2 & InSIGHT \\
\hline & c. $676 \mathrm{C}>\mathrm{T}$ & p.R226X & 8 & Causal & Argentina & 1 & InSIGHT \\
\hline & c. $677 \mathrm{G}>\mathrm{A}$ & p.R226Q & 8 & Causal & Argentina, Brazil & 3 & InSIGHT \\
\hline & $c .677+5 G>A$ & & 8 & Likely causal & Chile & 1 & French MMR network \\
\hline & c. $779 \mathrm{~T}>\mathrm{G}$ & p.L260R & 9 & Causal & Brazil & 1 & InSIGHT \\
\hline & $c .790+1 G>A$ & & 9 & Causal & Chile, Colombia & 3 & InSIGHT \\
\hline & $\begin{array}{l}\text { c.791- } \\
\text { 6_793delgtttagATC }{ }^{a}\end{array}$ & & 10 & Causal & Brazil & 1 & $\begin{array}{l}\text { Valentin et al. } \\
2011[3]\end{array}$ \\
\hline & c.794G > C & p.R265P & 10 & VUS & Chile & 1 & InSIGHT \\
\hline & c. $901 \mathrm{C}>\mathrm{T}$ & p.Q301X & 11 & Causal & Chile & 1 & InSIGHT \\
\hline & c. $1013 \mathrm{~A}>\mathrm{G}^{\mathrm{a}}$ & p.N338S & 11 & VUS & Brazil & 1 & InSIGHT \\
\hline & $c .1038+1 G>T^{a}$ & p.Y347FfsX13 & 11 & Causal & Chile & 1 & Wielandt et al. 2012 \\
\hline & $\begin{array}{l}\text { c.1039-8T_1558? } \\
\text { 896Tdup }{ }^{\mathrm{a}}\end{array}$ & p.520Vfs564X & 12 to 13 & Causal & Colombia & 2 & $\begin{array}{l}\text { Alonso-Espinaco et al. } \\
2011[11]\end{array}$ \\
\hline & c. $1276 C>T$ & p.Q426X & 12 & Causal & Brazil & 3 & InSIGHT \\
\hline & c. $1459 C>T$ & p.R487X & 13 & Causal & Brazil & 1 & InSIGHT \\
\hline & c.1499_1501delTCA ${ }^{a}$ & p.1500del & 13 & Causal & Brazil & 1 & Rossi et al. 2002 [5] \\
\hline & c. $1558+1 G>T$ & & 13 & Causal & Brazil & 1 & InSIGHT \\
\hline & c. $1558+14 \mathrm{G}>\mathrm{A}$ & & 13 & VUS & Colombia & 2 & InSIGHT \\
\hline & C. $1559-2 A>C$ & & 13 & Causal & Chile & 1 & InSIGHT \\
\hline & c.1559-?_1731 + ?del & p.V520_S577 > GfsX7 ${ }^{b}$ & $14-15$ & Causal & Chile & 1 & Wielandt et al. 2012 \\
\hline & c.1639_1643dup TTATA & p.L549YfsX44 & 14 & Causal & Brazil & 1 & $\begin{array}{l}\text { Valentin et al. } 2011 \\
\text { [3] }\end{array}$ \\
\hline & c.1690_1693delCTCA & p.L564FfsX26 & 15 & Causal & Brazil & 1 & InSIGHT \\
\hline & c. $1724 G>A$ & p.R575K & 15 & VUS & Argentina & 1 & InSIGHT \\
\hline & $c .1731+3 A>T^{a}$ & Skipping exon 15 & 15 & Causal & Chile & 1 & Alvarez et al. 2010 [6] \\
\hline & c.1846delAAG & p.K616del & 16 & Causal & Argentina & 1 & InSIGHT \\
\hline & c.1852_1853delinsGC & p.K618A & 16 & Causal & Argentina & 1 & InSIGHT \\
\hline & c.1852_1854 delAAG & p.K618del & 16 & Causal & Argentina & 1 & InSIGHT \\
\hline & c. $1853 A>C$ & p.K618T & 16 & VUS & Brazil & 1 & InSIGHT \\
\hline & c.1853delAinsTTCT" & p.K618lfsX4 & 16 & Causal & Brazil & 2 & $\begin{array}{l}\text { Valentin et al. } \\
2011[3]\end{array}$ \\
\hline
\end{tabular}


Table 2 Spectrum of alterations in South American Lynch syndrome families (Continued)

\begin{tabular}{|c|c|c|c|c|c|c|c|}
\hline & c.1856delG ${ }^{\mathrm{a}}$ & & 16 & Causal & Colombia & 2 & Giraldo et al. 2005 [2] \\
\hline & c.1890dup ${ }^{a}$ & p.D631fsX1 & 16 & Causal & Argentina & 1 & $\begin{array}{l}\text { Valentin et al. } \\
2011 \text { [3] }\end{array}$ \\
\hline & c.1897-?_1989+?del $\left.\right|^{\mathrm{a}}$ & & $17-19$ & Causal & Brazil & 1 & $\begin{array}{l}\text { Not previously } \\
\text { described }\end{array}$ \\
\hline & c. $1918 C>T$ & p.P640T & 17 & VUS & Colombia & 1 & InSIGHT \\
\hline & c. $1975 C>T$ & p.R659X & 17 & Causal & Brazil & 1 & InSIGHT \\
\hline & C.1998G > A & p.W666X & 18 & Causal & Brazil & 1 & Rossi et al. 2012 [5] \\
\hline & c.2027 T > C & p.L676P & 18 & Causal & Brazil & 1 & InSIGHT \\
\hline & c. $2041 G>A$ & p.A681T & 18 & Likely causal & $\begin{array}{l}\text { Chile, Brazil, } \\
\text { Colombia }\end{array}$ & 4 & French MMR network \\
\hline & c.2092_2093delTC & p.S698RfsX5 & 18 & Causal & Chile & 1 & Alvarez et al. 2010 [6] \\
\hline & c. $2224 \mathrm{C}>\mathrm{T}^{\mathrm{a}}$ & p.Q742X & 19 & Causal & Brazil & 1 & $\begin{array}{l}\text { Valentin et al. } \\
2011 \text { [3] }\end{array}$ \\
\hline & c.2252_2253dupAA & p.V752KfsX26 & 19 & VUS & Brazil & 1 & InSIGHT \\
\hline & c.2104-?_2271 + ?del $\left.\right|^{b}$ & p.S702_X757del & 19 & Causal & Chile & 2 & Wielandt et al. 2012 \\
\hline MSH2 & c.71delA ${ }^{a}$ & p.Q24fs & 1 & Causal & Brazil & 1 & $\begin{array}{l}\text { Not previously } \\
\text { described }\end{array}$ \\
\hline & c. $166 \mathrm{G}>\mathrm{T}^{\mathrm{a}}$ & p.E56X & 1 & Causal & Argentina & 1 & InSIGHT \\
\hline & c.174dupC $C^{\mathrm{a}}$ & & 1 & Causal & Brazil & 1 & $\begin{array}{l}\text { Not previously } \\
\text { described }\end{array}$ \\
\hline & c. 175 dupC $^{\mathrm{a}}$ & p.K59Qfs X23 & 1 & Causal & Brazil & 1 & $\begin{array}{l}\text { Valentin et al. } \\
2011 \text { [3] }\end{array}$ \\
\hline & c. $181 C>T^{a}$ & p.Q61X & 1 & Causal & Uruguay & 1 & Sarroca et al. 2003 \\
\hline & c.187delG & p.V63fs X1 & 1 & Causal & Brazil & 1 & InSIGHT \\
\hline & c. $289 \mathrm{C}>\mathrm{T}$ & p.Q97X & 2 & Causal & Argentina & 1 & InSIGHT \\
\hline & c.212-?_366 + ?del & p.A72_K122> FfsX9 & 2 & Causal & Chile & 1 & InSIGHT \\
\hline & c.388_389delCA & p.Q130VfsX2 & 3 & Causal & Brazil, Argentina & 2 & InSIGHT \\
\hline & c.530_531delAA ${ }^{a}$ & p.E177fsX3 & 3 & Causal & Uruguay & 1 & Sarroca et al. 2003 \\
\hline & c.596delTG ${ }^{\mathrm{a}}$ & & 3 & Causal & Colombia & 1 & Giraldo et al. 2005 [2] \\
\hline & $c .862 C>T$ & p.Q287X & 5 & Causal & Brazil & 1 & InSIGHT \\
\hline & c.897 T> G & p.Y299X & 5 & Causal & Chile & 1 & Wielandt et al. 2012 \\
\hline & c. $942+3$ A $>T$ & & 5 & Causal & Brazil & 1 & InSIGHT \\
\hline & c.1077-?_1276 + ?del & p.L360KfsX16 & 7 & Causal & Argentina & 1 & InSIGHT \\
\hline & c. $1147 C>T$ & p.R382X & 7 & Causal & Brazil & 1 & InSIGHT \\
\hline & c. $1215 C>A$ & p.Y405X & 7 & Causal & Chile & 1 & InSIGHT \\
\hline & c. $1216 C>T$ & p.R406X & 7 & Causal & Uruguay & 1 & InSIGHT \\
\hline & c.1249delG & p.V417LfsX21 & 7 & Causal & Brazil & 1 & InSIGHT \\
\hline & c. $1255 C>T$ & p.Q419X & 7 & Causal & Brazil & 1 & InSIGHT \\
\hline & c. $1444 \mathrm{~A}>\mathrm{T}^{\mathrm{a}}$ & p.R482X & 9 & Causal & Brazil & 1 & $\begin{array}{l}\text { Valentin et al. } \\
2011 \text { [3] }\end{array}$ \\
\hline & c.1447G > T & p.E483X & 9 & Causal & Brazil & 2 & InSIGHT \\
\hline & c. $1667 \mathrm{de}^{\mathrm{a}} \mathrm{T}^{\mathrm{a}}$ & p.L556X & 11 & Causal & Brazil & 1 & $\begin{array}{l}\text { Valentin et al. } \\
2011 \text { [3] }\end{array}$ \\
\hline & c.1667_1668insA a $^{a}$ & p.T557DfsX5 & 11 & Causal & Brazil & 1 & Rossi et al. 2002 [5] \\
\hline & c.1910delC ${ }^{a}$ & p.R638GfsX47 & 12 & Causal & Argentina & 1 & Vaccaro et al. 2007 \\
\hline & c.1967_1970dupACTT ${ }^{\mathrm{a}}$ & p.F657LfsX3 & 12 & Causal & Brazil & 1 & $\begin{array}{l}\text { Valentin et al. } \\
2011[3]\end{array}$ \\
\hline
\end{tabular}


Table 2 Spectrum of alterations in South American Lynch syndrome families (Continued)

\begin{tabular}{|c|c|c|c|c|c|c|}
\hline c. $2038 C>T$ & p.R680X & 13 & Causal & Chile & 1 & InSIGHT \\
\hline c.2046_2047delTG ${ }^{\mathrm{a}}$ & p.V684Dfs*14 & 13 & Causal & Argentina & 1 & InSIGHT \\
\hline$c .2131 C>T$ & p.R711X & 13 & Causal & Brazil & 1 & InSIGHT \\
\hline c. $2152 C>T$ & p.Q718X & 13 & Causal & Brazil & 6 & InSIGHT \\
\hline c.2185_2192del7insCCCT ${ }^{\mathrm{a}}$ & $\begin{array}{l}\text { P. } \\
\text { M729_E731delinsP729_X730 }\end{array}$ & 13 & Causal & Chile & 1 & Alvarez et al. 2010 [6] \\
\hline$c .2187 \mathrm{G}>\mathrm{T}^{\mathrm{a}}$ & p.M729| & 13 & VUS & Brazil & 1 & $\begin{array}{l}\text { Valentin et al. } \\
2011[3]\end{array}$ \\
\hline c.2525_2526delAG ${ }^{a}$ & p.E842VfsX3 & 15 & Causal & Brazil & 2 & $\begin{array}{l}\text { Valentin et al. } \\
2011[3]\end{array}$ \\
\hline c. $2785 \mathrm{C}>\mathrm{T}^{\mathrm{a}}$ & p.R929X & 16 & Causal & Brazil & 1 & $\begin{array}{l}\text { Valentin et al. } \\
2011 \text { [3] }\end{array}$ \\
\hline
\end{tabular}

${ }^{a}$ First reported, VUS variants of unclassified significance, MLH1 (MIM\#120436), MSH2 (MIM\#609309), ${ }^{b}$ pathogenecity demonstration ongoing.

$\mathrm{ca} / \mathrm{mmrvariants} /$ ), the French MMR network (http://www. umd.be/MMR.html) and the International Society for Gastrointestinal Hereditary Tumors (InSIGHT) (http:// www.insight-group.org).

\section{Variants of uncertain significance}

To establish the pathogenicity of variants of uncertain significance, web-based programs, i.e. Polyphen, MAPPMMR, SIFT, P-mut and PON-MMR were applied to predict the effect of an amino acid substitution based on protein structural change and/or evolutionary conservation [13-17].

\section{Statistical analysis}

The statistical analyses were performed using the statistical software package IBM SPSS Statistics 20 (SPSS, Chicago, IL, USA).

\section{Results}

In total, 110 families harbored MMR gene variants, of which 99 were classified as Lynch syndrome predisposing and 11 were regarded as variants of uncertain significance. Mutations in $M L H 1$ and $M S H 2$ were identified in $37 \%$ (range $27-65 \%$ in the different countries/registries) of the families that fulfilled the Amsterdam criteria and/ or Bethesda guidelines (Table 1). When the Amsterdam criteria were considered, the mutation detection rate was $55 \%$ (81/147), whereas $15 \%$ families that fulfilled the Bethesda guidelines had disease-predisposing mutations. The mean age at diagnosis was 35-44 years for colorectal cancer and 41-49 years for endometrial cancer in the different registries (Table 1). Pedigree information was available from 54 families and showed that among the Lynch syndrome-associated tumors, $65 \%$ were colorectal cancers (of which $43 \%$ were located in the right side of the colon), $22 \%$ endometrial cancers and 13\% constituted other Lynch syndrome-associated cancer types.
Of the 99 disease-predisposing MMR gene mutations, $60 \%$ affected $M L H 1$ and $40 \%$ affected MSH2 (Table 2). Frameshift and nonsense mutations were the most common alterations (36\% and 31\%, respectively), followed by splice site mutations (13\%), missense mutations (12\%) and large deletions (8\%) (Figure 2a). Though the mutations were spread over the genes, hot-spot regions included exons 16 and 18 in MLH1 (13\% of the mutations

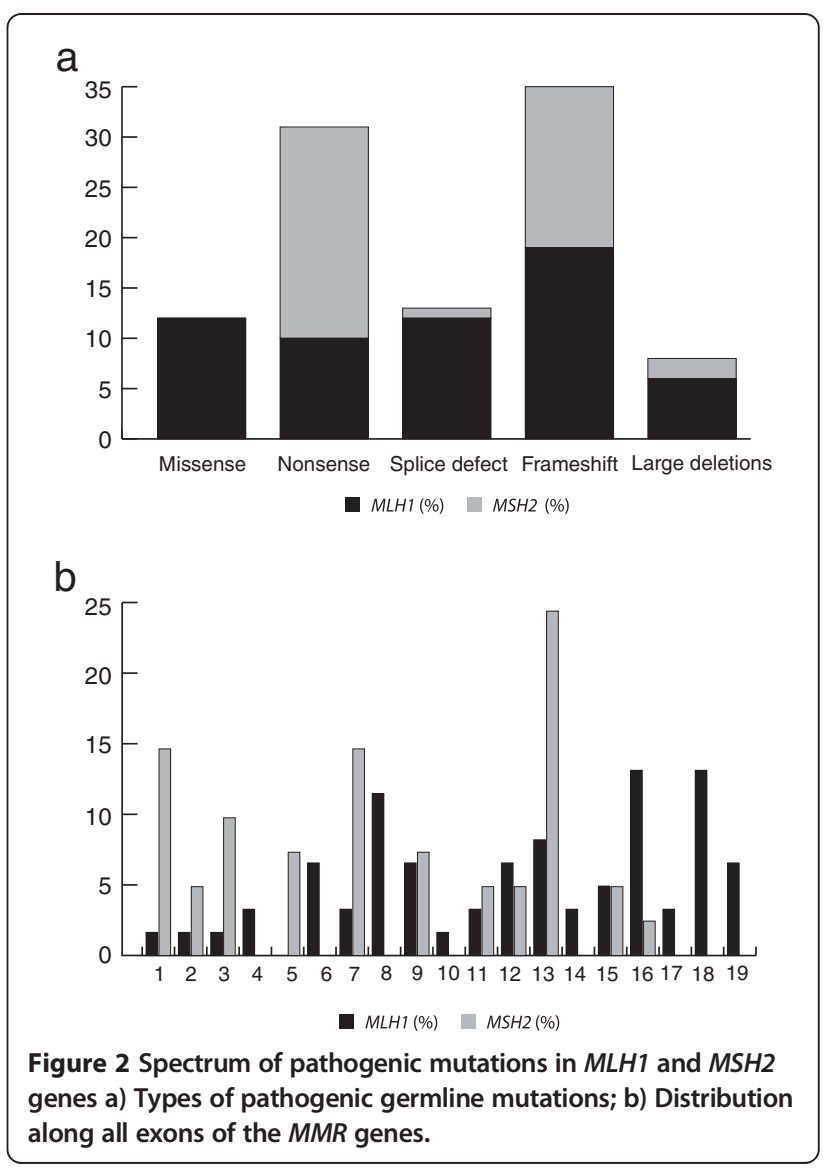


each) and exon 13 in $M S H 2$ (24\% of the mutations each) (Figure 2b).

In total, 10 mutations identified in at least two South American families were classified as recurrent. Among these, the MSH2 c.2152C > T identified in Brazil represents an internationally hot-spot. Three founder mutations were identified in five South American families. The MLH1 c. $545+3 \mathrm{~A}>\mathrm{G}$ and the $M S H 2$ c. $942+3 \mathrm{~A}>\mathrm{T}$ have been identified as founder mutations in Italy and in Newfoundland and were also identified in Brazilian families [3]. The MLH1 c.1039-8T_1558 + 896Tdup has been suggested to represent a founder mutation in Colombia $[2,11]$. Mutations that were unique and herein first reported in more than one family included the $M L H 1$ c.1853delAinsTTCTT in Brazil, the MLH1 c.1856delG in Colombia and the MSH2 c.25252_2526delAG in Brazil (Table 2) (Figure 3).

In total, 11 variants of unclassified significance were identified in individuals from Argentina, Uruguay, Chile, Brazil and Colombia (Table 3) [2,3]. In silico analysis suggested

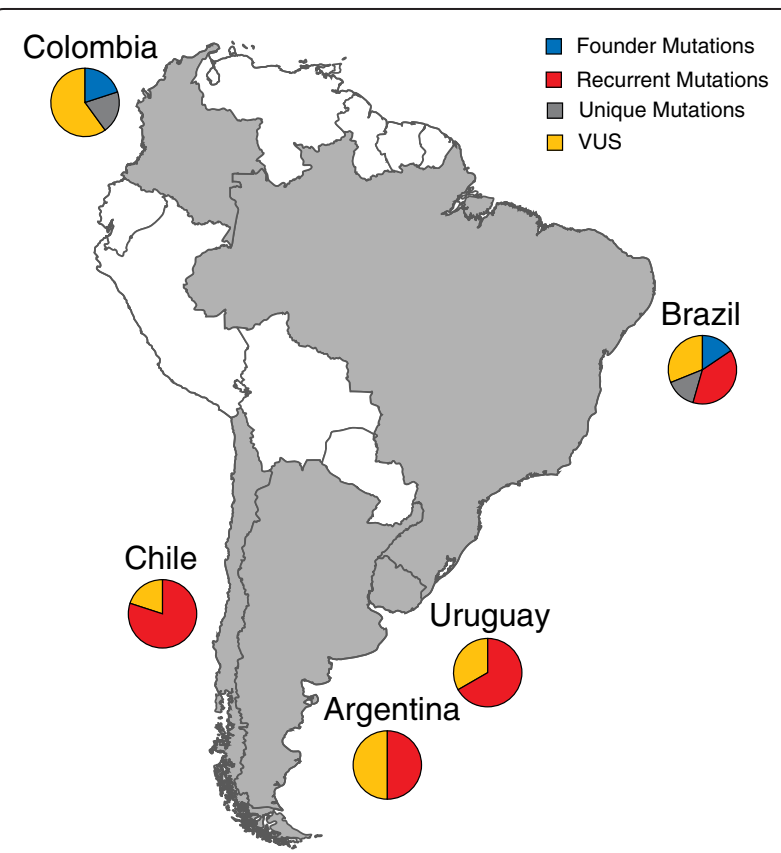

Figure 3 Map of South America showing the countries where Lynch syndrome families with the founder, recurrent, unique mutations and variants of unclassified significance (VUS) have been identified. The figure depicts the countries participating in the study (gray). The pie chart represents in percentage the recurrent mutations, unique mutations, founder mutations and VUS identified in the South American families. Brazil is characterized by $16 \%$ of the founder mutations, $39 \%$ of the recurrent mutations, $14 \%$ of the unique mutations and $31 \%$ of the VUS, while Colombia by $20 \%$ of the founder mutations, $20 \%$ of the unique mutations and $60 \%$ of the VUS. Chile, Argentina and Uruguay are characterized by $80 \%, 50 \%$ and $67 \%$ of the recurrent mutations and $20 \%, 50 \%$ and $33 \%$ of the VUS, respectively. that the MLH1 c.289 T>G, the MLH1c.794G >C and the MLH1c.1918C > T were likely disease-predisposing (Table 3).

\section{Discussion}

In South America, disease-predisposing mutations linked to Lynch syndrome have been identified in 99 families, which corresponds to $37 \%$ of the families that fulfilled the Amsterdam criteria and/or Bethesda guidelines and underwent genetic testing. The mutation rate is high compared to prevalence rates of $28 \%$ for $M L H 1$ and $18 \%$ for $M S H 2$ in the Asian population, $31 \%$ and $20 \%$ in a multi-ethnic American population and 26\% and $19 \%$ in European/Australian populations [18]. The mutation spectrum is predominated by $M L H 1$ (60\%) and MSH2 (40\%) mutations [3,19-22], but the seemingly larger contribution than the $42 \%$ and $33 \%$ reported in the InSIGHT database could reflect failure to test for MSH6 and PMS2 mutations in most South American studies [1]. Referral bias in populations that have more recently been screened for mutations represents a potential limitation, but the strong contribution from $M L H 1$ and $M S H 2$ could also reflect population structure $[2,4,5,7]$. Frameshift mutations and nonsense mutations were the most common types of mutations, which are in agreement with findings from other populations [1,23-26], with hotspots in exons 16 and 18 of $M L H 1$ and in exon 13 of $M S H 2$ (Figure 2b). Exon 16 and 18 in $M L H 1$ has been identified as a genetic hot spot also in other populations with $26 \%$ of the MLH1 mutations reported herein $[3,18]$. The frequent mutations in $M S H 2$ exon 13 may be linked to the c. $2152 \mathrm{C}>$, which was first identified in Portuguese Lynch syndrome families. This alteration accounted for $35 \%(6 / 17)$ of the $M S H 2$ mutations in the Brazilian population, which is in line with the Portuguese migration to Brazil [3,27].

Founder mutations have been identified in several populations where they significantly contribute to disease predisposition and thereby allow for directed genetic testing [28]. Two of the mutations identified in South American Lynch syndrome families have been suggested to constitute potential founder mutations in other populations, e.g. the Italian $M L H 1$ c. $545+3 \mathrm{~A}>\mathrm{G}$ and the Newfoundland MSH2 c.942+3A > T [3]. The Spanish founder mutations $M L H 1$ c. $306+5 \mathrm{G}>\mathrm{A}$ and c. $1865 \mathrm{~T}>\mathrm{A}$ and $M S H 2$ c.2635-3 T > C; c2635-5C > T; c.2063 T > G were, however, not observed in South American Lynch syndrome families [27-30]. In Colombia, the $M S H 2$ c.1039-8T_1558+896Tdup was suggested to represent a founder mutation [2,11]. The Colombian population has a mixed ancestry with a strong influence from Spanish colonists and thereby genetically differs from previously studied populations $[2,6]$. 
Table 3 Variants of unclassified significance and in silico prediction in South American Lynch syndrome families

\begin{tabular}{|c|c|c|c|c|c|c|c|c|c|c|c|c|c|c|}
\hline \multirow[t]{2}{*}{ Country } & \multirow[t]{2}{*}{ Gene } & \multirow[t]{2}{*}{ Nucleotide } & \multirow[t]{2}{*}{ Consequence } & \multirow[t]{2}{*}{ Exon } & \multicolumn{2}{|c|}{ Polyphen } & \multicolumn{2}{|l|}{ SIFT } & \multicolumn{2}{|c|}{ MAP_MMR } & \multicolumn{2}{|l|}{ P-mut } & \multicolumn{2}{|c|}{ PON-MMR } \\
\hline & & & & & Score & Classification & Score & Classification & Score & Classification & Score & Classification & Score & Classification \\
\hline Uruguay & MLH1 & c.289 T>G & p.Y97D & 3 & 0.999 & Probably damaging & 0 & Damaging & 10.51 & Damaging & 0.7266 & Pathological & 0.83 & Pathogenic \\
\hline Argentina & MLH1 & c.336 T > A & p.H112Q & 4 & 1 & Probably damaging & 0.03 & Damaging & 2.430 & Neutral & NA & NA & 0.61 & VUS \\
\hline Colombia & MLH1 & $c .421 C>G$ & p.P141A & 5 & 0.329 & Benign & 0.05 & Damaging & 3.15 & Borderline deleterious & 0.4928 & Neutral & 0.48 & VUS \\
\hline Chile & MLH1 & c. $794 G>C$ & p.R265P & 10 & 1 & Probably damaging & 0 & Damaging & 38.09 & Damaging & 0.7623 & Pathological & 0.83 & Pathogenic \\
\hline Brazil & MLH1 & c. $1013 A>G$ & p.N338S & 11 & 0.506 & Possibly Damaging & 0.05 & Damaging & 2.78 & Neutral & 0.2551 & Neutral & 0.38 & VUS \\
\hline Colombia & MLH1 & c. $1558+14 G>A$ & & 13 & NA & NA & NA & NA & NA & NA & NA & NA & NA & NA \\
\hline Argentina & MLH1 & c. $1724 \mathrm{G}>\mathrm{A}$ & p.R575K & 15 & 0.001 & Benign & 0.40 & Tolerated & 1.490 & Neutral & NA & NA & 0.15 & Neutral \\
\hline Brazil & MLH1 & c. $1853 A>C$ & p.K618T & 16 & 0.997 & Probably damaging & 0.02 & Damaging & 5.11 & Damaging & 0.7802 & Pathological & 0.67 & VUS \\
\hline Colombia & MLH1 & c. $1918 C>$ T & р.Р640T & 17 & 1 & Probably damaging & 0 & Damaging & 17.77 & Damaging & 0.6534 & Pathological & 0.83 & Pathogenic \\
\hline Brazil & MLH1 & c.2252_2253dupAA & p.V752Kfs*26 & 19 & NA & NA & NA & NA & NA & NA & NA & NA & NA & NA \\
\hline Brazil & MSH2 & c. $2187 \mathrm{G}>\mathrm{T}$ & p.M729| & 13 & 2.293 & Probably damaging & 0 & Damaging & 21.99 & Damaging & 0.1988 & Neutral & 0.71 & VUS \\
\hline
\end{tabular}

MLH1 (MIM\#120436), MSH2 (MIM\#609309), NA: not applicable, VUS: variants of unclassified significance, If SIFT score $<0.05$ then the aminoacid (AA) substitution is predicted to affect protein function, if PolyPhen score $>0.5$ then the AA substitution is predicted to affect protein function, if MAPP-MMR score $>4.55$ then the AA substitution is predicted to affect protein function, If P-mut score $>0.5$, the AA substitution is classified as pathological, if PON-MMR score $>0.7615$, the AA substitution is classified as pathogenic. 


\section{Conclusions}

In conclusion, disease-predisposing mutations in $M L H 1$ and $M S H 2$ have been identified in a relatively large proportion of the South American families suspected of Lynch syndrome that have been tested. Genetic hot-spot regions, internationally recognized founder mutations and potential South American founder mutation have been recognized, which is of relevance for genetic counseling and testing that are increasingly available in South America.

Competing interests

The authors declare that they have no competing interests.

\section{Authors' contributions}

MDV, MN, BMR participated in the conception and design of the study. All authors participated in the acquisition of data, or analysis, interpretation of data and have been involved in drafting the manuscript. All authors read and approved the final manuscript.

\section{Author details}

${ }^{1}$ The Danish HNPCC Register, Clinical Research Centre, Hvidovre Hospital, Copenhagen University, Hvidovre, Denmark. ²Department of Oncology, Institute of Clinical Sciences, Lund University, Lund, Sweden. ${ }^{3}$ Department of Experimental Medical Science, Unit of Muscle Biology, Lund Transgenic Core Facility/Reproductive Immunology, Lund University, Lund, Sweden.

${ }^{4}$ Molecular Laboratory, Clinica Los Condes, Santiago, Chile. ${ }^{5}$ Hereditary Cancer Program, Hospital Italiano, Buenos Aires, Argentina. ${ }^{6}$ Hospital Fuerzas Armadas, Grupo Colaborativo Uruguay de Investigación de Afecciones Oncológicas Hereditarias (GCU), Montevideo, Uruguay. ${ }^{7}$ Department of Oncogenetics, Barretos Cancer Hospital, Barretos, Brazil. ${ }^{8}$ Facultad de Medicina de la Universidad del Sinú, Montería, Colombia. ${ }^{9}$ Department of Genetics UFRGS, Hospital de Clínicas, Porto Alegre, Brazil. ${ }^{10}$ Department of Molecular Oncogenetics, Laboratory of Genomics and Molecular Biology, AC Camargo Hospital, Sao Paulo, Brazil. ${ }^{11}$ Hospital Sirio Libanes, Sao Paulo, Brazil.

Received: 27 August 2013 Accepted: 12 December 2013

Published: 18 December 2013

\section{References}

1. Plazzer JP, Sijmons RH, Woods MO, Peltomaki P, Thompson B, DenDunnen JT, Macrae F: The InSiGHT database: utilizing 100 years of insights into Lynch Syndrome. Fam Cancer 2013, 12:175-180.

2. Giraldo A, Gomez A, Salguero G, Garcia H, Aristizabal F, Gutierrez O, Angel LA, Padron J, Martinez C, Martinez H, et al: MLH1 and MSH2 mutations in Colombian families with hereditary nonpolyposis colorectal cancer (Lynch syndrome)-description of four novel mutations. Fam Cancer 2005, 4:285-290.

3. Valentin MD, da Silva FC, dos Santos EM, Lisboa BG, de Oliveira LP, Ferreira Fde O, Gomy I, Nakagawa WT, Aguiar Junior S, Redal M, et al: Characterization of germline mutations of MLH1 and MSH2 in unrelated south American suspected Lynch syndrome individuals. Fam Cancer 2011, 10:641-647.

4. Sarroca C, Valle AD, Fresco R, Renkonen E, Peltomaki $\mathrm{P}$, Lynch H: Frequency of hereditary non-polyposis colorectal cancer among Uruguayan patients with colorectal cancer. Clin Gen 2005, 68:80-87.

5. Rossi BM, Lopes A, Oliveira Ferreira F, Nakagawa WT, Napoli Ferreira CC, Casali Da Rocha JC, Simpson CC, Simpson AJ: hMLH1 and hMSH2 gene mutation in Brazilian families with suspected hereditary nonpolyposis colorectal cancer. Ann Surg Oncol 2002, 9:555-561

6. Alvarez K, Hurtado C, Hevia MA, Wielandt AM, de la Fuente M, Church J, Carvallo P, Lopez-Kostner F: Spectrum of MLH1 and MSH2 mutations in Chilean families with suspected Lynch syndrome. Dis Colon Rectum 2010, 53:450-459.

7. Vaccaro CA, Bonadeo F, Roverano AV, Peltomaki P, Bala S, Renkonen E, Redal MA, Mocetti E, Mullen E, Ojea-Quintana G, et al: Hereditary nonpolyposis colorectal cancer (Lynch Syndrome) in Argentina: report from a referral hospital register. Dis Colon Rectum 2007, 50:1604-1611.
8. Vasen HF, Mecklin JP, Khan PM, Lynch HT: The International Collaborative Group on Hereditary Non-Polyposis Colorectal Cancer (ICG-HNPCC). Dis Colon Rectum 1991, 34:424-425.

9. Vasen HF, Watson P, Mecklin JP, Lynch HT: New clinical criteria for hereditary nonpolyposis colorectal cancer (HNPCC, Lynch syndrome) proposed by the International Collaborative group on HNPCC. Gastroenterology 1999, 116:1453-1456.

10. Rodriguez-Bigas MA, Boland CR, Hamilton SR, et al: A national cancer institute workshop on hereditary nonpolyposis colorectal cancer syndrome: meeting highlights and Bethesda guidelines. J Natl Cancer Inst 1997, 89:1758-1762

11. Alonso-Espinaco V, Giraldez MD, Trujillo C, van der Klift H, Munoz J, Balaguer F, Ocana T, Madrigal I, Jones AM, Echeverry MM, et al: Novel MLH1 duplication identified in Colombian families with Lynch syndrome. Genet Med 2011, 13:155-160.

12. denDunnen JT, Antonarakis SE: Mutation nomenclature extensions and suggestions to describe complex mutations: a discussion. Hum Mutat 2000, 15:7-12

13. Adzhubei IA, Schmidt S, Peshkin L, Ramensky VE, Gerasimova A, Bork P, Kondrashov AS, Sunyaev SR: A method and server for predicting damaging missense mutations. Nat Methods 2010, 7:248-249.

14. Chao EC, Velasquez JL, Witherspoon MS, Rozek LS, Peel D, Ng P, Gruber SB Watson P, Rennert G, Anton-Culver $\mathrm{H}$, et al: Accurate classification of MLH1/MSH2 missense variants with multivariate analysis of protein polymorphisms-mismatch repair (MAPP-MMR). Hum Mutat 2008, 29:852-860.

15. Kumar P, Henikoff S, Ng PC: Predicting the effects of coding nonsynonymous variants on protein function using the SIFT algorithm. Nat Protoc 2009, 4:1073-1081.

16. Ferrer-Costa $C$, Orozco M, de la Cruz X: Sequence-based prediction of pathological mutations. Proteins 2004, 57:811-819.

17. Ali $\mathrm{H}$, Olatubosun $\mathrm{A}$, Vihinen $\mathrm{M}$ : Classification of mismatch repair gene missense variants with PON-MMR. Hum Mutat 2012, 33:642-650.

18. Li D, Hu F, Wang F, Cui B, Dong X, Zhang W, Lin C, Li X, Wang D, Zhao Y: Prevalence of pathological germline mutations of hMLH1 and hMSH2 genes in colorectal cancer. PloS One 2013, 8:e51240.

19. Dominguez MV, Bastos EP, Santos EM, Oliveira LP, Ferreira FO, Carraro DM, Rossi BM: Two new MLH1 germline mutations in Brazilian Lynch syndrome families. Int J Colorectal Dis 2008, 23:1263-1264.

20. da Silva FC, de Oliveira LP, Santos EM, Nakagawa WT, Aguiar Junior S, Valentin MD, Rossi BM, de Oliveira Ferreira F: Frequency of extracolonic tumors in Brazilian families with Lynch syndrome: analysis of a hereditary colorectal cancer institutional registry. Fam Cancer 2010, 9:563-570.

21. Monteiro Santos EM, Valentin MD, Carneiro F, de Oliveira LP, de Oliveira FF Junior SA, Nakagawa WT, Gomy I, de FariaFerraz VE, da Silva Junior WA, et al: Predictive models for mutations in mismatch repair genes: implication for genetic counseling in developing countries. BMC Cancer 2012, 12:64.

22. Valentin MD, Da Silva FC, Santos EM, Da Silva SD, De Oliveira FF, Aguiar Junior S, Gomy I, Vaccaro C, Redal MA, Della Valle A, et al: Evaluation of MLH1 I219V polymorphism in unrelated South American individuals suspected of having Lynch syndrome. Anticancer Res 2012, 32:4347-4351.

23. Peltomaki P, Vasen HF, The International Collaborative Group on Hereditary Nonpolyposis Colorectal Cancer: Mutations predisposing to hereditary nonpolyposis colorectal cancer: database and results of a collaborative study. Gastroenterology 1997, 113:1146-1158.

24. Apessos A, Mihalatos M, Danielidis I, Kallimanis G, Agnantis NJ, Triantafillidis JK, Fountzilas G, Kosmidis PA, Razis E, Georgoulias VA, Nasioulas G: hMSH2 is the most commonly mutated MMR gene in a cohort of Greek HNPCC patients. Br J Cancer 2005, 92:396-404.

25. Sjoblom T, Jones S, Wood LD, Parsons DW, Lin J, Barber TD, Mandelker D, Leary RJ, Ptak J, Silliman N, et al: The consensus coding sequences of human breast and colorectal cancers. Science 2006, 314:268-274.

26. Nilbert M, Wikman FP, Hansen TV, Krarup HB, Orntoft TF, Nielsen FC, Sunde L, Gerdes AM, Cruger D, Timshel S, et al: Major contribution from recurrent alterations and MSH6 mutations in the Danish Lynch syndrome population. Fam Cancer 2009, 8:75-83.

27. Isidro G, Veiga I, Matos P, Almeida S, Bizarro S, Marshall B, Baptista M, Leite J, Regateiro F, Soares J, et al: Four novel MSH2 / MLH1 gene mutations in portuguese HNPCC families. Hum Mutat 2000, 15:116. 
28. Borras E, Pineda M, Blanco I, Jewett EM, Wang F, Teule A, Caldes T, Urioste M, Martinez-Bouzas C, Brunet J, et al: MLH1 founder mutations with moderate penetrance in Spanish Lynch syndrome families. Cancer Res 2010, 70:7379-7391.

29. Menendez M, Castellvi-Bel S, Pineda M, de Cid R, Munoz J, Gonzalez S, Teule A, Balaguer F, Ramon y Cajal T, Rene JM, et al: Founder effect of a pathogenic MSH2 mutation identified in Spanish families with Lynch syndrome. Clin Gen 2010, 78:186-190.

30. Medina-Arana V, Barrios Y, Fernandez-Peralta A, Herrera M, Chinea N, Lorenzo N, Jimenez A, Martin-Lopez JV, Gonzalez-Hermoso F, Salido E, Gonzalez-Aguilera Jj: New founding mutation in MSH2 associated with hereditary nonpolyposis colorectal cancer syndrome on the Island of Tenerife. Cancer Lett 2006, 244:268-273.

\section{doi:10.1186/1897-4287-11-18}

Cite this article as: Dominguez-Valentin et al: Mutation spectrum in South American Lynch syndrome families. Hereditary Cancer in Clinical Practice 2013 11:18.

\section{Submit your next manuscript to BioMed Central and take full advantage of:}

- Convenient online submission

- Thorough peer review

- No space constraints or color figure charges

- Immediate publication on acceptance

- Inclusion in PubMed, CAS, Scopus and Google Scholar

- Research which is freely available for redistribution 